\title{
Propagation of the Kakegawa Strain of Bovine Coronavirus in Suckling Mice, Rats and Hamsters
}

\author{
Brief Report
}

\author{
By

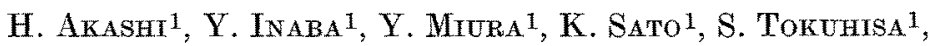 \\ M. ASAGI ${ }^{2}$, and Y. HAYASHI ${ }^{3}$ \\ 1 National Institute of Animal Health, \\ Tsukuba, Japan \\ 2 NIHON VACCNE Co. Ltd., \\ Nishinasuno, Tochigi, Japan \\ 3 ZEN-NOH Central Institute for Feed and Livestock Research, \\ Tsukuba, Japan \\ With 1 Figure
}

Accepted November 5, 1980

\begin{abstract}
Summary
The Kakegawa strain of bovine coronavirus was easily propagated in suckling mice. Infected animals died with nervous symptoms, and serial passage was readily accomplished by intracerebral inoculation with brain emulsions. The 3rd passage viral material from infected mice evoked the same disease in suckling mice, rats and hamsters inoculated by the intracerebral or by the subcutaneous route. Viruses recovered from mice, rats and hamsters could be clearly differentiated. from mouse hepatitis virus strain 2 by the neutralization test.
\end{abstract}

A bovine coronavirus (BCV) has been recognized as one of the causative agents of diarrhea in calves (8). Recently the Kakagawa strain isolated from the feces of a cow with epizootic diarrhea has been identified as BCV $(1,9)$. However, the study of bovine diarrheal disease produced by coronavirus has been greatly hampered by difficulty in isolating virus in cell cultures and the lack of experimental hosts other than eattle. Recently many members of the coronavirus family have been found to grow in suckling mice $(5-7)$. The present paper describes briefly our recent observation that the Kakegawa strain of $\mathrm{BCV}$ readily propagates in suckling mice, rats and hamsters.

The Kakegawa strain of BCV used for mouse inoculation was at the 10th passage level in primary bovine kidney cell cultures. Conventionally reared oneday-old mice (strain ddY), rats and Syrian hamsters were each inoculated with $0.01-\mathrm{ml}$ of the viral materials by the intracerebral (ic) route and with $0.02-\mathrm{ml}$ by 
the subcutaneous (s.c.) route. Virus recovery and infectivity assay were carried out by inoculation into cell cultures of BEK-1 cell, derived from bovine embryonic kidney (3). The anti-Kakegawa strain immune serum having a homologous neutralizing antibody titer of 4096 was prepared in specific germ-free rabbits with virus grown in BEK-1 cells as described previously (1), and the anti-mouse hepatitis virus (MHV) strain 2 rabbit immune serum having a neutralizing antibody titer of about 10,000 by 50 per cent plaque reduction neutralization test was kindly supplied by Dr. K. Fujiwara, University of Tokyo, Japan. Neutralization (NT) test was carried out by the method described previously (1). Viruses recovered from the brains of affected animals containing 200 TCID $_{50}$ were mixed with an equal volume of two-fold serum dilutions. Each mixture was assayed for infectivity by using two tubes of BEK-1 cell cultures per dilution. The antibody titer was expressed as the reciprocal of the highest serum dilution that showed no cytopathic changes in at least one of the two tubes.

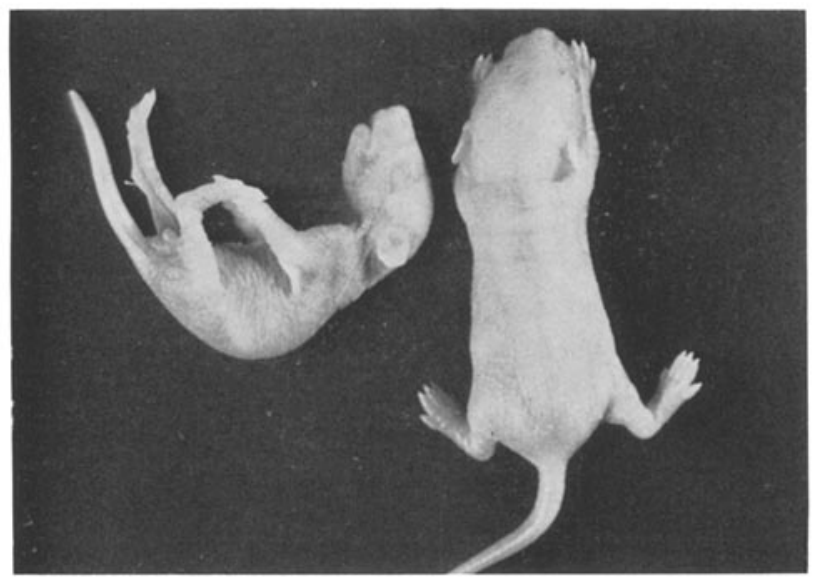

Fig. 1. Four-day-old mouse 3 days after intracerebral inoculation with the 3rd mouse brain passaged Kakegawa strain (left) and an uninoculated 4-day-old mouse (right)

Four litters ( 10 to 12 /itter) of suckling mice were inoculated intracerebrally with infected tissue culture fluid containing $10^{6.5} \mathrm{TCID}_{50} / \mathrm{ml}$. At daily intervals, four animals were sacrificed and their brains taken. The inoculated animals developed an illness 4 days post-inoculation (p.i.) and began to die at 5 days $p$. i. The affected animals became anemic and showed mild neural symptoms such as weak limbs and sluggish staggering gait. The virus titers of infected brains rose at 2 days p. i. with a subsequent gradual rise to a maximum of $10^{8.5}$ TCID $_{50} / g$ at 5 days p. i. Serial passage in suckling mice was readily accomplished by the i. c. route with 10 per cent (w/v) brain emulsions (Fig. 1). The incubation period fell to 2 to 3 days by the $3 r d$ passage. Uninoculated mice and mice inoculated with normal brain emulsions remained healthy. Virus at the 3rd passage level in suckling mice containing $10^{5.2} \mathrm{TCTD}_{50} / \mathrm{ml}$ also produced a clinical illness with the same symptoms described above. It caused death in all animals when incoulated into one litter of suckling mice (10/litter) by the s.c. route, and into rats (9 or 12/litter) and hamsters ( 7 or $8 /$ litter) by the i.c. or s.c. route. 
Table 1. Neutralization of the viruses recovered from the brains of affected animals with the anti-Kakegawa strain of bovine coronavirus and the anti-mouse hepatitis virus (MHV) strain 2 rabbit immune serum

\begin{tabular}{lll}
\hline & \multicolumn{2}{c}{ Neutralizing antibody titer } \\
\cline { 2 - 3 } Virus & $\begin{array}{l}\text { Anti-Kakegawa } \\
\text { strain }\end{array}$ & $\begin{array}{l}\text { Anti-MHV } \\
\text { strain 2 }\end{array}$ \\
\hline Mouse i.c. ${ }^{a}$ & 2048 & 16 \\
Mouse s.c. & 1024 & 16 \\
Rat i.c. & 1024 & 16 \\
Hamster i.c. & 1024 & 16 \\
\hline
\end{tabular}

a Viruses recovered from the brains of affected mice by the intracerebral (i.c.) or the subcutaneous (s.c.) inoculation with the 3 rd passage viral materials ins suekling mice

The results of one way cross NT test are summarized in Table 1 . The homologous NT titers were much higher than the heterologous titers. These findings showed that the viruses recovered from the brains of affected animals were antigenically the same as the cell culture passaged virus and could be clearly differentiated from the MHV strain 2.

A histological study of affected animals showed inflammation in the brains and vacuolar degeneration of the intestinal villi only in the case of s.c. inoculation. However, there was no evidence of inflammation in the liver and other organs (Dr. M. Kubo, personal communication).

KAYE et al. (4) reported that they had adapted the American strain of calf diarrhea coronavirus to suckling mouse brain. On the other hand, DEA et al. (2) reported that the American strain and their new isolates of calf diarrhea coronavirus were not virulent for suckling mice, hamsters and guinea pigs. Our present results support Kaye's findings. NT tests and histological studies have ruled out contamination with MHV. Further studies, however, will be necessary to investigate the immunological and pathological differences between $\mathrm{BCV}$ and $\mathrm{MHV}$.

\section{References}

1. Akashi, H., Inaba, Y., Mivra, Y., Tokumisa, S., Sato, K., Satoda, K. : Properties of a coronavirus isolated from a cow with epizootic diarrhea. Vet. Mierobiol. 5, 265$276(1980)$.

2. Dra, S., Rot, R. S., Begin, M. E.: Physicochemical and biological properties of neonatal calf diarrhea coronaviruses isolated in Quebec and comparison with the Nebraska calf coronavirus. Amer. J. vet. Res. 41, 23-29 (1980).

3. Iraba, Y., Sato, K., Kurogi, H., Tarahashi, E., Ito, Y., Omori, T., Goto, Y., Matumoto, M. : Replication of bovine coronavirus in cell line BEK-1 culture. Arch. Virol. 50, 339-342 (1976).

4. KAYE, H. S., YARbrough, W. B., ReED, C. J. : Calf diarrhoea coronavirus. Lancet ii, $509(1975)$.

5. Kaye, H. S., Yarbrough, W. B., Reed, C. J., Harrison, A. K.: Antigenic relationship between human coronavirus strain $\mathrm{OC} 43$ and hemagglutinating encephalomyelitis virus strain $67 \mathrm{~N}$ of swine: Antibody responses in human and animal sera. J. inf. Dis. 135, 201-209 (1977).

6. MoIntosh, K.: Coronaviruses: A comparative review. Curr. Top. Microbiol. Immunol. 63, 85-129 (1974). 
370 H. AkashI et al.: Propagation of Bovine Coronavirus in Laboratory Animals

7. Osterhaus, A. D. M. E., Horzinek, M. C., Wiramadirfedja, R. M. S.: Feline Infectious Peritonitis Virus. II. Propagation in suckling mouse brain. Zbl. Vet. Med. B 25, 301-307 (1978).

8. Statr, E. L., Rhodes, M. B., Whrte, R. G., Mebus, C. A. : Neonatal calf diarrhea: Purification and electron microscopy of a coronavirus-like agent. Amer. J. Vet. Res. $33,1147-1156(1972)$.

9. Takahashi, E., Inaba, Y., Sato, K., Itro, Y., Kurogt, H., AKashi, H., Satoda, K., Omori, T. : Epizootic diarrhoea of adult cattle associated with a coronavirus-like agent. Vet. Mierobiol. 5, 151-154 (1.980).

Authors' address: Dr. H. Akashi, National Institute of Animal Health, Tsukuba, Ibaraki 305, Japan.

Received August 8, 1980

Heransgeber, Gigentümer und Verleger: Springer-Verlag, Molkerbastel 5 , A-1011 Wien. Fur den Textteil verantwortlich: Dr. Wilhelm Schwabl, Mölkerbastei 5, A-1011 Wien. Für den Anzeigenteil verantwortlich: Mag. Bruno Schweder, Mölkerbastei 5, A-1011 Wien. Druck: R. Spies \& Co., Stranßengasse 16, A-1050 Wien.

Printed in Austria. 